Article

\title{
An IoT-Based Traceability Platform for Wind Turbines
}

\author{
Jinjing An ${ }^{1,2}$, Guoping Chen ${ }^{1, *}$, Zhuo Zou ${ }^{1}$, , Yaojie Sun ${ }^{1}$, Ran Liu ${ }^{1}$ and Lirong Zheng ${ }^{1, *}$ \\ 1 School of Information Science and Technology, Fudan University, Shanghai 200433, China; \\ jjan15@fudan.edu.cn (J.A.); zhuo@fudan.edu.cn (Z.Z.); yjsun@fudan.edu.cn (Y.S.); rliu@fudan.edu.cn (R.L.) \\ 2 Project Management Department, Wuxi Institute of Fudan University, Wuxi 214131, China \\ * Correspondence: gpchenapple@fudan.edu.cn (G.C.); lrzheng@fudan.edu.cn (L.Z.)
}

check for

updates

Citation: An, J.; Chen, G.; Zou, Z.; Sun, Y.; Liu, R.; Zheng, L. An IoT-Based Traceability Platform for Wind Turbines. Energies 2021, 14, 2676. https://doi.org/10.3390/en14092676

Academic Editor: Sandro Nizetic

Received: 6 April 2021

Accepted: 2 May 2021

Published: 6 May 2021

Publisher's Note: MDPI stays neutral with regard to jurisdictional claims in published maps and institutional affiliations.

Copyright: (c) 2021 by the authors. Licensee MDPI, Basel, Switzerland. This article is an open access article distributed under the terms and conditions of the Creative Commons Attribution (CC BY) license (https:// creativecommons.org/licenses/by/ $4.0 /)$.

\begin{abstract}
In recent years, the application of traceability systems in the food and drug industry has developed rapidly, but it is rarely used for wind turbines. From the aspects of low information transparency and information islands in the supply chain process for wind turbines, a reliable traceability system is essential. However, the existing traceability systems are not suitable to be directly applied to wind turbines. Consequently, according to the characteristics of the wind power industry, a semi-centralized traceability architecture based on Internet of Things technology was proposed. Furthermore, a traceability platform was constructed by analyzing the information collected in each stage related to various user needs of wind turbines, and various applications, including manufacturing management and spare parts management, were developed. Compared with the existing systems, the proposed platform was wind-turbine-oriented, effectively improved traceability efficiency and enterprises' information security, and extended the length of the traceability chain by integrating the after-sales information. The traceability of key components of wind turbines during their life cycle provides a useful reference for further improving the parts quality management system of the wind power industry.
\end{abstract}

Keywords: wind turbine; traceability system; Internet of Things

\section{Introduction}

Renewable energy sources are acknowledged as promising alternatives to reduce fossil-fuel-based resource consumption. Wind energy is a type of renewable energy with abundant reserves. Furthermore, large-scale wind turbines are considered to be the most affordable among all renewable energy sources [1]. Although wind power generation has an impact on human life, including high noise and visual impacts, as well as the rotor blades causing the deaths of birds and bats, it still can effectively lessen the environmental impact burden and pollutant emissions [2]. The utilization rate of wind energy is directly affected by the weather, especially wind conditions. Several main technical indexes need to be comprehensively considered in the process of wind energy resource evaluation: average wind speed, wind power density, dominant wind direction, wind distribution, diurnal and annual wind speed patterns, annual wind energy utilization time, wind shear coefficient, potential annual energy production from a turbine, and so on [3].

In recent years, due to the gradual maturity of wind power technology and continuous decline in the cost of wind power generation, wind turbines have been widely used. The rated power of wind turbines has ranged from dozens of kilowatts to megawatts [4]. With the development of large-scale wind turbines, the coupling effect of various parts in the process of energy transfer has become more complex. For this reason, multiple protection and redundancy designs have been adopted to guarantee operation safety, which can result in frequent failures. The failure of a component during operation can cause the shutdown of wind turbines, even resulting in irreparable consequences. The cause of a failure can be analyzed in a timely manner only by quickly obtaining the relevant data of key components of wind turbines, which can be achieved through a traceability system. Consequently, it is of great significance to study the traceability systems of wind turbines. 
Traceability is defined as 'the ability to trace the history, application or location of an entity by means of that which is under consideration' [5]. The traceability industry has maintained a sustained and stable development trend in industries that are closely related to people's lives, such as the medicine, food, agricultural product, and automotive industries. However, the application of traceability systems in the life cycle of wind turbines has not been thoroughly studied. Moreover, it should be noted that the existing traceability systems are not suitable to be directly applied to wind turbines. In the food and medicine fields, the main purpose of traceability systems is to clarify the responsibility, recall defective products quickly, and encourage enterprises to improve product quality. By comparison, in wind turbines, the goal of traceability is mostly focused on the effective use of traceability data, which makes the users pay more attention to the after-sales stages than the stages from production to sales. Therefore, it is necessary to study a new traceability system that is suitable for wind turbines.

As one of the key technologies in traceability systems, the Internet of Things (IoT) has been widely used in a variety of things and objects, which can interact with each other and cooperate with their neighbors through unique addressing schemes [6,7]. Due to bridging the gap between the cyber and physical worlds and providing interoperability and compatibility, the IoT has been recognized as one of the most promising networking paradigms in the world [8,9]. IoT technology can identify objects quickly and collect, record, transmit, and store information accurately, which greatly improves traceability efficiency and reduces errors [10]. In the energy sector, to meet the challenges of modern energy, the use of sensors and automation systems for production management, monitoring, and automation will become the norm in the near future in most manufacturing enterprises [11]. Moreover, IoT can also help the energy sector transform from a central, hierarchical supply chain to a decentralized, smart, and optimized system [12]. These lay a foundation for building traceability systems in the wind power industry.

The existing traceability systems can be roughly divided into systems with a centralized architecture and systems with a distributed architecture. Compared to the centralized system, the distributed system has higher cost performance, stronger processing capacity, higher reliability, and better scalability. Meanwhile, as a response to distributed energy, wind energy enterprises should implement more decentralized systems that can meet the expectations of the environment, the economy, and society [13]. However, the distributed system has problems with data tampering and information disclosure. Given the large scale of both manufacturing enterprises of wind turbines and wind farms, a semi-centralized IoT-based traceability architecture was proposed in this study. The proposed architecture can fully integrate all data types, disperse data pressure, improve traceability efficiency, and effectively protect enterprise business information. Based on the proposed architecture, a new traceability platform for wind turbines was developed by studying the characteristics of the key components of wind turbines, the information collected during each stage, and various user needs. The developed platform extends the traceability chain by increasing the amount of collected information on the operation, maintenance, recycling, and disposal stages to realize the traceability of the whole life cycle.

The remainder of the paper is organized as follows. In Section 2, related work about wind turbines and traceability systems is reviewed. Different requirements of various users of wind turbines are summarized and analyzed in Section 3. In Section 4, the architecture of the proposed IoT-based platform is described. A prototype system is introduced in Section 5. The characteristics of the prototype system are discussed in Section 6. The conclusion and future work are presented in Section 7.

\section{Related Work}

\subsection{Studies on Wind Turbines}

In recent years, in order to improve the performance of wind turbines, a lot of studies about fault diagnosis, failure data analysis, and reliability assessment have been carried out. Warnock et al. [14] presented a study of offshore wind transmission systems' reliability 
and the result showed that the experienced failure rates are subject to a much higher spread in practice than those published. Su et al. [15] discovered that the failure rates of electrical and control systems were high, while the corresponding repair time was relatively short; the failure rates of the main shaft, gearbox, and generator were relatively low, while the average time for maintenance was comparably long. Pinar Pérez et al. [16] discovered that components such as gears, blades, or hydraulics were the most problematic from the aspects of failure rate and downtime per failure, causing a high downtime. Faulstich et al. [17] analyzed statistical data obtained by Germany's 250 MW Wind Program and found that 25\% of all failures were responsible for $95 \%$ of the downtime, while the other $75 \%$ of the failures were responsible for only 5\% of downtime. Guo et al. [18] proposed a novel method based on data-driven multiscale dictionary construction, which can extract the fault characteristics from measured signals more efficiently than the traditional methods. Florescu et al. [19] designed a functional hollow roller model to provide an internal automated lubrication system for the large bearings of wind turbines.

In terms of reliability research regarding wind turbines, modeling and simulation have gradually become a research hotspot. Papatzimos et al. [20] proposed a data-driven model for predicting wind turbine faults and sending timely alarms for a range of subassemblies through quantifying the relationship between the alarms and failures, and the results showed an overall accuracy of $99.3 \%$ for the two-year data. Slimacek et al. [21] analyzed the reliability of wind turbines using a simple mathematical model based on a Poisson process and found that wind turbines with advanced techniques had lower failure rates than other wind turbines. Using a dynamic vector approach, Syahputra et al. [22] presented modeling and simulation for doubly-fed wind turbines. Shin et al. [23] established a simplified semi-analytical computational fluid dynamics model to study the interference effect on the wake of multiple wind turbines. Donadio et al. [24] proposed two power prediction models based on the hybridization of numerical weather prediction (NWP) and artificial neural networks (ANN), which can provide accurate power forecasts for wind farms with high terrain and flow complexities.

\subsection{Studies on the Applications of IoT in Wind Turbines}

Nowadays, IoT technologies are mainly used in condition monitoring or the fault prediction of wind turbines. Ahuir-Torres et al. [25] designed an IoT-based miniaturized wireless sensor network system for the autonomous corrosion detection and monitoring of offshore wind turbines. Liew et al. [26] developed an IoT-based environmental and working conditions monitoring system for wind turbines, which can monitor, capture, and diagnose problems for small three-blade Savonius wind turbines. Noor et al. [27] proposed an IoT-based communication framework between wind turbines and their control centers, which can help to predict the state of a wind turbine closely. Based on the bidirectional long short-term memory neural network and particle filter technology, Zhou et al. [28] used IoT technologies and proposed a remaining life prediction method for the wind turbine drive system, which can simplify the feature processing flow effectively. For predicting the long cycle maintenance time of wind turbines, Yeh et al. [29] collected operation data, maintenance time data, and event codes through IoT technologies and then proposed a hybrid network training prediction model based on a convolutional neural network (CNN) and a support vector machine (SVM). IoT can also be used for improving energy efficiency and reducing the impact of energy use on the environment. Tao et al. [30] investigated some applications of IoT technologies in manufacturing to reduce energy consumption during the processes of design, production, and operation. Motlagh et al. [12] classified different use cases of IoT in the energy supply chain, from power generation to end-use sectors, and discussed the advantages of IoT-based energy management systems in increasing energy efficiency and integrating renewable energy. 


\subsection{Studies on IoT-Based Traceability Systems}

In recent years, a number of studies on IoT-based traceability systems have been published, and many effective traceability methods and models have been proposed. Luo et al. [31] designed a food traceability platform that was based on a distribution framework, which can provide traceability, production, and management services for food enterprises and also provide various methods for food traceability for the public. Visconti et al. [32] proposed a smart IoT-based traceability and farm management system, which can calibrate irrigations and fertigation operations. Wei [33] proposed a data traceability platform architecture for supply chain management based on multidisciplinary knowledge and technology. Liu et al. [34] introduced a pilot project in China named the Internet of Agricultural Things, which integrates state-of-the-art technologies to provide a method for easy tracking and tracing of food supply processes. In [35], the enterprise-oriented name service designed for agricultural products was presented, and it was deployed across five cities to enable the efficient storage and retrieval of information about agricultural products. A food traceability system supported by a trusted service based on domain name system security extensions, which ensures that information stored in an enterprise database is original and can never be manipulated, was designed and implemented in [36]. Appelhanz et al. [37] proposed a traceability information system for capturing, processing, and provision of product information using examples of wood furniture, which can increase consumers' trust and purchase intentions toward eco-friendly products. Rempel et al. [38] suggested that traceability could be of great practical value for any type of software development project; their study considered four main implementation requirements for supporting activities. Wang et al. [39] developed a distributed trace coordination design by leveraging in-place traceability to better support the development and evolution of automated production systems. Vukatana et al. [40] developed an agile and automated traceability system based on the GS1 specifications for a wine supply chain.

In order to solve the problem of data security in the process of traceability, some blockchain-technology-based traceability systems have been developed [41]. Tian [42] presented a traceability system based on RFID and blockchain technologies to enhance food safety and quality and reduce losses in logistics. Lin et al. [43] designed a decentralized system based on the blockchain and EPCIS network, including the collaborative management of on- and off-chain data and the enterprise-level smart contracture. Cao et al. [44] developed a blockchain-based IoT traceability system for steel quality by adopting the alliance chain mode and the Hyperledger blockchain platform. Tsang et al. [45] proposed a blockchain-IoT-based food traceability system, in which the shelf life of perishable food was managed using fuzzy logic.

As presented, traceability systems have been successfully applied to many industries. Most of these industries are intended for mass production, such as food and medicine, but none of them is wind-turbine-oriented. For this reason, it is important to study the traceability system for wind turbines.

\section{Methods}

\subsection{User Requirements Analysis}

\subsubsection{Design Requirements}

Failures of wind turbines can be caused by unreasonable design, such as teeth fracture and oil leakage of a gearbox. Therefore, a proper design of wind turbines is crucial.

Taking the main control system of wind turbines as an example, there have still been deficiencies in many aspects, such as information collection and storage, accurate fault reporting, anti-interference, and remote fault diagnosis and processing, due to which, the requirements of wind turbines maintenance cannot be met. Due to external interference, a false shutdown alarm increases the difficulty of analyzing and judging potential failures, as well as the maintenance cost.

Therefore, in the design stage of a wind turbine and its components, it is necessary to consider the problems that are related to component maintenance, on-site fault analysis, 
judgment, and treatment. For instance, by designing tools and methods properly, remote fault diagnosis and fault-tolerant operation can be performed on a remote control center. In addition, severe environmental conditions of wind farms should be fully considered in the design stage.

\subsubsection{Manufacturing Requirements}

Many common faults of wind turbines are caused by unqualified raw materials or defective production processes. For instance, main shaft fractures are mainly caused by high hydrogen content in the material, which can be mitigated by strengthening supplier management. The loosening of planetary gears in the gearbox is caused by an unreasonable production process, and the deformation of the yaw reducer is caused by defects in the assembly process.

According to the actual requirements of the manufacturing enterprises of a wind turbine and its components, a traceability function is urgently needed. For instance, through the tracking and monitoring of electrical components, production processes, machinery, equipment, personnel shifts, finished products, and semi-finished products, all relevant information on unqualified products can be promptly and accurately traced, including the information on products' components, batches, and flow direction of the products' batches. Furthermore, by tracing the inspection information in the production process, the information on the original inspection records, inspectors, inspection time, and measuring instruments, as well as whether unqualified products have been used and how they are handled can be acquired.

\subsubsection{Wind Farm Requirements}

According to the installed location, wind turbines can be divided into onshore wind turbines and offshore wind turbines. Onshore wind turbines are usually located in inaccessible lands, such as grasslands, plateaus, and mountain areas; meanwhile, offshore wind turbines are located in the sea. Furthermore, the engine room of a wind turbine is installed at the top of the tower, which is tens of meters high. Therefore, the operating environments of wind turbines are very harsh.

Under these circumstances, almost every wind turbine will be shut down in its design life, which is usually 20 25 years. A slight fault will cause the shutdown of wind turbines and the reduction of power generation, while serious faults will cause great loss to wind farms because of the extremely high cost of maintenance, parts replacement, hoisting, and transportation. A faulty wind turbine can work only after on-site or remote maintenance. Therefore, in order to ensure the long-term, stable, and safe operation of wind turbines, it is necessary to reduce and avoid potential faults and carry out preventive maintenance smoothly.

\subsubsection{Regulatory Authority Requirements}

The regulatory authorities of the wind power industry have the responsibility to ensure different operations, including a safe electricity supply, reliability management, emergency management, early warning, and many others.

Namely, in a case where defective products have been sold, the regulatory authorities need to have the information on the exact flow direction of these products in time such that they can launch recall notices as soon as possible and inform all relevant manufacturers about the problem. In addition, for defective products that have been put into use, the regulatory authorities need to analyze their batch, quantity, location, and other relevant information and release the corresponding information to the public in time.

\subsection{Structure of Wind Turbines}

A wind turbine can be divided into five levels: raw materials, parts, sub-components, components, and a wind turbine. Users' requirements for traceability accuracy can differ. The wind farm needs to trace only a wind turbine and its key components, a manufacturer 
of wind turbines needs to trace purchased components and important sub-components, and a manufacturer of components needs to trace their parts. Considering its practical significance, the traceability of a wind turbine, as well as its key components, was the focus of this study.

A wind turbine is mainly composed of a rotor, a nacelle, a tower, and a base, including a variety of mechanical, electrical, and control components. In order to assess the importance of the main components of wind turbines, five factors, including the value, probability of disqualification, the difficulty of maintenance and replacement, the difficulty of after-sale service, and the impact on wind turbines were selected. Through the comprehensive analysis of the above aspects, the components of wind turbines that need to be focused on were screened out.

In order to make the assessment more effective and objective, the expert scoring method was adopted in this work. The score range of each factor was 1-10. A score higher than or equal to 9 was listed as high, a score between 7 and 9 (including 7) was seen as 'below high', a score between 4 and 7 (including 4 ) belonged to the medium range, and a score lower than 4 belonged to the low range. Each component was evaluated according to the average score.

The results are shown in Table 1.

Table 1. Analysis of the key components of a wind turbine.

\begin{tabular}{|c|c|c|c|c|c|}
\hline Component & Value & $\begin{array}{c}\text { Probability of } \\
\text { Disqualification }\end{array}$ & $\begin{array}{c}\text { Difficulty of } \\
\text { Maintenance and } \\
\text { Replacement }\end{array}$ & $\begin{array}{c}\text { Difficulty of } \\
\text { After-Sale Service }\end{array}$ & $\begin{array}{l}\text { Impact on Wind } \\
\text { Turbines }\end{array}$ \\
\hline Generator & $\mathrm{H}$ & $\mathrm{M}$ & $\mathrm{H}-$ & $\mathrm{H}-$ & $\mathrm{H}$ \\
\hline Blades & $\mathrm{H}$ & $\mathrm{H}-$ & $\mathrm{H}-$ & $\mathrm{H}-$ & $\mathrm{H}$ \\
\hline Nacelle casting & $\mathrm{H}-$ & $\mathrm{M}$ & $\mathrm{H}$ & $\mathrm{H}-$ & $\mathrm{H}-$ \\
\hline Rotor hub & $\mathrm{H}-$ & $\mathrm{M}$ & $\mathrm{H}$ & $\mathrm{H}-$ & $\mathrm{H}-$ \\
\hline $\begin{array}{l}\text { The main } \\
\text { control system }\end{array}$ & H- & $\mathrm{L}$ & H- & M & $\mathrm{H}$ \\
\hline Gearbox & $\mathrm{M}$ & $\mathrm{H}$ & $\mathrm{H}$ & $\mathrm{H}-$ & $\mathrm{H}$ \\
\hline Pitch bearing & $\mathrm{M}$ & $\mathrm{L}$ & $\mathrm{H}-$ & $\mathrm{H}$ & $\mathrm{H}$ \\
\hline Converter & M & $\mathrm{H}-$ & $\mathrm{H}-$ & $\mathrm{H}-$ & $\mathrm{H}-$ \\
\hline Yaw brake disc & $\mathrm{L}$ & $\mathrm{L}$ & M & $\mathrm{M}$ & $\mathrm{M}$ \\
\hline $\begin{array}{l}\text { High-strength } \\
\text { fasteners }\end{array}$ & $\mathrm{L}$ & L & $\mathrm{M}$ & L & $\mathrm{M}$ \\
\hline $\begin{array}{c}\text { Brake system } \\
\text { Iiohtning }\end{array}$ & $\mathrm{L}$ & $\mathrm{L}$ & $\mathrm{L}$ & $\mathrm{L}$ & $\mathrm{M}$ \\
\hline $\begin{array}{l}\text { protection } \\
\text { device }\end{array}$ & $\mathrm{L}$ & $\mathrm{L}$ & L & $\mathrm{L}$ & M \\
\hline
\end{tabular}

Note: $\mathrm{H}$ denotes high, $\mathrm{H}$ - denotes 'below high', $\mathrm{M}$ denotes medium, and $\mathrm{L}$ denotes low.

According to a comprehensive analysis of the above results, the generator, blades, nacelle casting, rotor hub, main control system, gearbox, converter, and pitch bearing were regarded as the key components of a wind turbine in this study. Accordingly, their design reliability, manufacturing quality, and operation and maintenance level in the traceability process were studied. It should be noted that the traceability focus was different for different components. For instance, for a gearbox, great attention should be paid to the temperature of the lubricating oil and bearing, while for a converter, attention should be paid to the power device since it is the core of the converter.

\subsection{Electronic Product Code System}

Regarding the traceability systems, the Electronic Product Code (EPC) system has been considered to be the most appealing system in the world, which can identify the goods in the supply chain more quickly, automatically, and accurately. The EPC system is in compliance with standards from the EPCglobal organization [46]. 
The EPC system is composed of an EPC code, an radio-frequency identification (RFID) system, and an EPC information network system. The EPC code is compatible with EAN/UPC codes and is jointly managed, maintained, and applied by EPCglobal, national EPC management organizations, and managers of items. The RFID is a non-contact identification technology that uses radio frequency signals to identify target objects, and it includes readers, antennas, electronic tags, and other related hardware and software [47]. The EPC information network system is used to realize information management and information circulation, and it is composed of EPC middleware, the Object Name Service (ONS), and an information service (IS). The ONS is the core technology of the EPC system [48]. In 2013, the GS1 published the ONS 2.0 standard that enables the use of the GS1 identification keys, which introduced the federated model to solve the cooperating name service problem [49]. The RFID tag is the information carrier of the EPC system. Furthermore, an RFID reader is used to read the EPC code and transmit the information to the middleware of the EPC information network system. When a manufacturer assembles a product and attaches an RFID tag with a unique EPC, all subscribers of the EPCglobal network can retrieve all relevant information of the product from the manufacturer's database according to their need [50]. The EPCglobal network manages the EPC-related product information obtained from the RFID tags [51].

Due to the high significance of the EPC system in practice, it was applied in this work.

\section{System Design}

\subsection{IoT-Based System Architecture}

Considering the demands of various users and the pressure of data aggregation, a semi-centralized IoT-based traceability architecture was proposed. The proposed architecture is shown in Figure 1, where it can be seen that it consists of four layers: a data acquisition layer, a data transmission layer, a platform layer, and an application layer. The standard identification system and the information security system support the design and implementation of all layers.

By integrating the internal management information systems of manufacturers and wind farms and the supply chain information systems of other participants, the full life cycle traceability of wind turbines is realized. Moreover, enterprises involved in all stages can be identified based on the information flow in the supply chain.

Each of the layers of the proposed platform is introduced in the following.

\subsection{Data Acquisition Layer}

In the data acquisition layer, most of the data involved in the life cycle of a wind turbine are obtained and pre-processed. This process consists of the design stage, raw material acquisition stage, production, and manufacturing stage, testing and certification stage, transaction and transportation stage, installation stage, and operation and maintenance stage.

The collected data are divided into four types: information on the enterprises, information on the products, information on the location and environment, and information on the events. The detailed information on each stage of a wind turbine is shown in Table 2. 


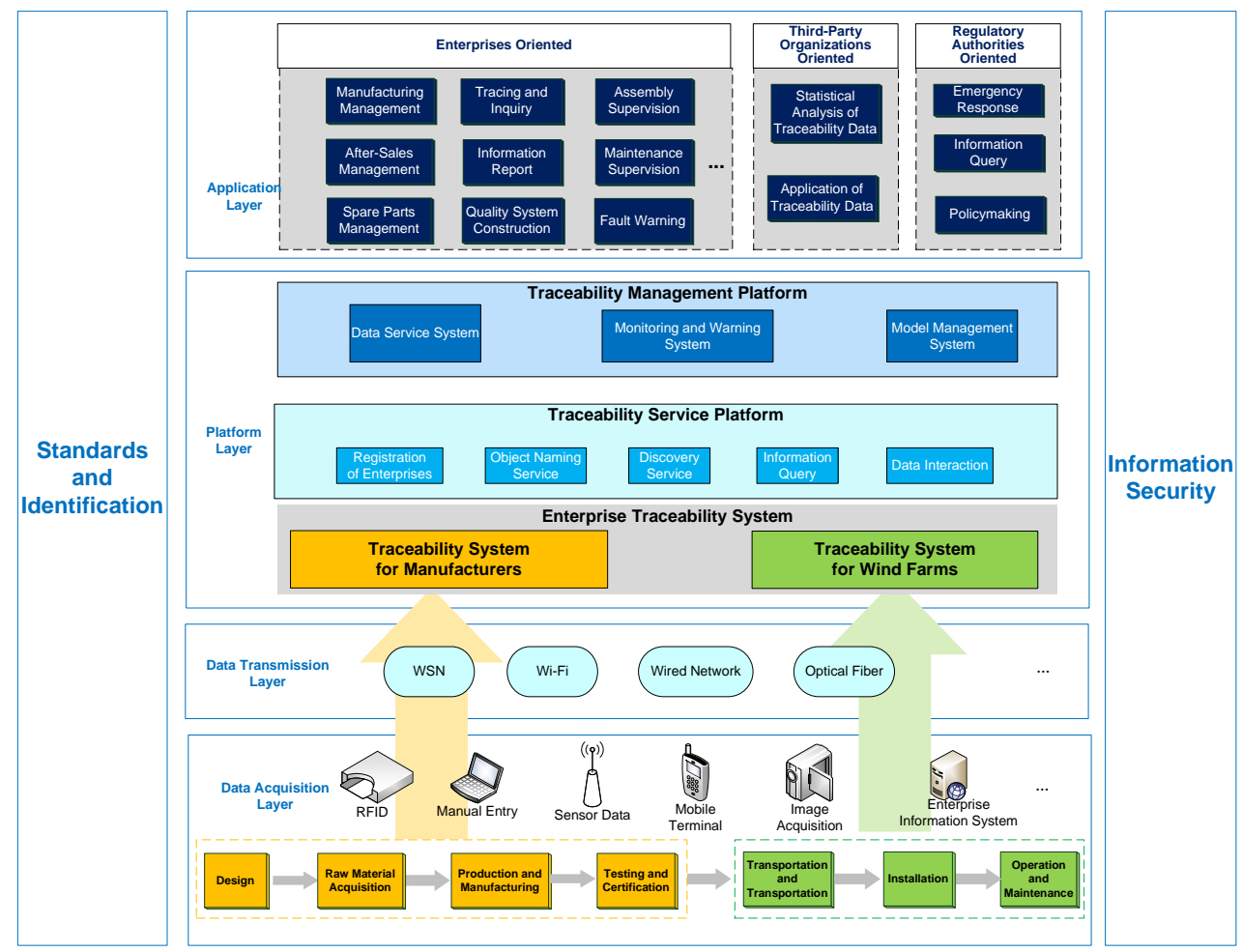

Figure 1. The architecture of the proposed IoT-based traceability platform for wind turbines.

Table 2. The detailed information on each stage of wind turbines.

\begin{tabular}{|c|c|c|c|c|c|c|c|}
\hline Stage & Design & $\begin{array}{c}\text { Raw } \\
\text { Material } \\
\text { Acquisition }\end{array}$ & $\begin{array}{l}\text { Production and } \\
\text { Manufacturing }\end{array}$ & $\begin{array}{l}\text { Testing and } \\
\text { Certification }\end{array}$ & $\begin{array}{l}\text { Transaction and } \\
\text { Transportation }\end{array}$ & Installation & $\begin{array}{c}\text { Operation } \\
\text { and } \\
\text { Maintenance }\end{array}$ \\
\hline $\begin{array}{l}\text { Information } \\
\text { on enter- } \\
\text { prises }\end{array}$ & $\begin{array}{l}\text { Design } \\
\text { enter- } \\
\text { prises }\end{array}$ & $\begin{array}{l}\text { Raw material } \\
\text { suppliers }\end{array}$ & $\begin{array}{l}\text { Manufacturing } \\
\text { enterprises, } \\
\text { workers } \\
\text { involved }\end{array}$ & $\begin{array}{l}\text { Testing and } \\
\text { certification } \\
\text { organiza- } \\
\text { tions }\end{array}$ & $\begin{array}{c}\text { Transportation } \\
\text { enterprises, } \\
\text { drivers, } \\
\text { traders }\end{array}$ & $\begin{array}{c}\text { Installation } \\
\text { enterprises, } \\
\text { installation } \\
\text { personnel }\end{array}$ & $\begin{array}{l}\text { Operation } \\
\text { and } \\
\text { maintenance } \\
\text { enterprises of } \\
\text { wind farms }\end{array}$ \\
\hline $\begin{array}{l}\text { Information } \\
\text { on } \\
\text { products }\end{array}$ & $\begin{array}{l}\text { Design } \\
\text { docu- } \\
\text { ments }\end{array}$ & $\begin{array}{l}\text { Raw material } \\
\text { information }\end{array}$ & $\begin{array}{c}\text { Product } \\
\text { information, } \\
\text { bill of materials }\end{array}$ & $\begin{array}{l}\text { Product } \\
\text { information } \\
\text { on testing } \\
\text { and } \\
\text { certification }\end{array}$ & $\begin{array}{c}\text { Product } \\
\text { information of } \\
\text { transaction and } \\
\text { transportation }\end{array}$ & $\begin{array}{c}\text { Product } \\
\text { information } \\
\text { of installation }\end{array}$ & $\begin{array}{l}\text { Operation } \\
\text { data of wind } \\
\text { turbines, } \\
\text { information } \\
\text { on spare } \\
\text { parts }\end{array}$ \\
\hline $\begin{array}{l}\text { Information } \\
\quad \text { on } \\
\text { location } \\
\text { and envi- } \\
\text { ronment }\end{array}$ & $\begin{array}{l}\text { Location } \\
\text { and envi- } \\
\text { ronment } \\
\text { of design } \\
\text { enter- } \\
\text { prises }\end{array}$ & $\begin{array}{c}\text { Location and } \\
\text { environment } \\
\text { of raw } \\
\text { materials } \\
\text { production }\end{array}$ & $\begin{array}{l}\text { Location and } \\
\text { environment of } \\
\text { manufacturing } \\
\text { and } \\
\text { storage }\end{array}$ & $\begin{array}{l}\text { Location and } \\
\text { environment } \\
\text { on testing } \\
\text { and } \\
\text { certification }\end{array}$ & $\begin{array}{c}\text { Transportation } \\
\text { route, } \\
\text { trading location }\end{array}$ & $\begin{array}{l}\text { Location and } \\
\text { environment } \\
\text { of the } \\
\text { installation }\end{array}$ & $\begin{array}{c}\text { Location and } \\
\text { environment } \\
\text { of wind } \\
\text { farms }\end{array}$ \\
\hline $\begin{array}{l}\text { Information } \\
\text { on events }\end{array}$ & $\begin{array}{l}\text { Design } \\
\text { qualifica- } \\
\text { tion } \\
\text { certificate }\end{array}$ & $\begin{array}{l}\text { Raw material } \\
\text { qualification } \\
\text { certificate }\end{array}$ & $\begin{array}{l}\text { Equipment used, } \\
\text { technological } \\
\text { process, } \\
\text { manufacturing } \\
\text { time, } \\
\text { information on } \\
\text { access to the } \\
\text { warehouse }\end{array}$ & $\begin{array}{c}\text { Date, } \\
\text { personnel, } \\
\text { items, and } \\
\text { results of } \\
\text { testing and } \\
\text { certification }\end{array}$ & $\begin{array}{c}\text { Vehicles, } \\
\text { transportation } \\
\text { time, } \\
\text { trading time, } \\
\text { delivery } \\
\text { information }\end{array}$ & $\begin{array}{l}\text { Installation } \\
\text { date, } \\
\text { installation } \\
\text { process, } \\
\text { used } \\
\text { equipment, } \\
\text { certificate of } \\
\text { completion }\end{array}$ & $\begin{array}{c}\text { Fault } \\
\text { information, } \\
\text { maintenance } \\
\text { information } \\
\text { (repair, } \\
\text { overhaul } \\
\text { component } \\
\text { replacement) }\end{array}$ \\
\hline
\end{tabular}


The information on enterprises can be obtained via manual inputs and it includes names, identifications, addresses, websites, responsible person information, relevant qualifications, and all other relevant information about enterprises. It should be noted that it is necessary to ensure the authenticity and effectiveness of the data. The information on products (e.g., name, identification, quantity, batch number, the bill of materials, main product parameters, and qualification certificate) can be acquired from the enterprise information systems (EIS) on the basis of transforming the enterprise data interface. The information on location and environment can be acquired by global positioning systems, video supervising equipment, and other information sensing equipment. Among them, the environmental information in the manufacturing stage will be mainly focused on. The information on events can be obtained with the help of RFID devices, barcode identification equipment, and other equipment.

\subsection{Data Transmission Layer}

The data transmission layer transfers data that is collected by the data acquisition layer to the servers in the platform layer through a network (e.g., wireless sensor network (WSN), Wi-Fi, or a wired network).

\subsection{Platform Layer}

The platform layer stores and analyses all collected data and it consists of the enterprise traceability system (ETS), traceability service platform (TSP), and traceability management platform (TMP).

\subsubsection{Enterprise Traceability System}

Considering the characteristics of the wind power industry, both the manufacturing enterprises of wind turbines and the wind farms are large-scale enterprises and have their own enterprise information system. Therefore, the ETS is divided into a traceability system for manufacturers and a traceability system for wind farms. The information obtained from the design, raw material acquisition, production and manufacturing, inspection and testing, and transportation stages is transferred to the traceability system for manufacturers. Meanwhile, the information obtained from the transaction and transportation, installation, operation, and maintenance stages is transferred to the traceability system for wind farms. For this reason, the ETS will be constructed by the manufacturing enterprises of wind turbines and wind farms, and the enterprises in charge of design, raw material supply, testing, logistics, installation, and disposal will help to enrich the ETS.

The ETS includes the data interface middlewares, traceability databases, and operation support modules. The data interface middlewares transform the data of different structures and store these data in traceability databases. The operation support modules mainly perform the functions of user management, identity management, data management, service resource management, security management, and query and statistics modules.

\subsubsection{Traceability Service Platform}

The TSP is responsible for the aggregation, cleaning, association, and transformation of the relevant data submitted by the ETS, and provides the data support service for the traceability management platform. All types of information in the supply chain of wind turbines are uploaded to the TSP through the data interface middlewares of the ETS.

Based on the EPCglobal network, the TSP consists of the discovery service (DS), which provides a list of the ETSs that are associated with a target product, and the ONS offering a network address of a DS in response to a user query. ONS is the core application service of the IoT, which can help to achieve the unification of the underlying data structure and the query of information.

In the TSP, data collection, storage, aggregation, management, and information queries are realized using the ONS, and all the corresponding server addresses of the ETS can be obtained by querying the identities. On this basis, the identification query, identification 
discovery, and identification search services are established. Before providing services, manufacturing enterprises and wind farms need to provide their information and register on the identity management server, as well as maintain their domain names in the traceability database of the ETS.

The operation process of the traceability service platform is shown in Figure 2.

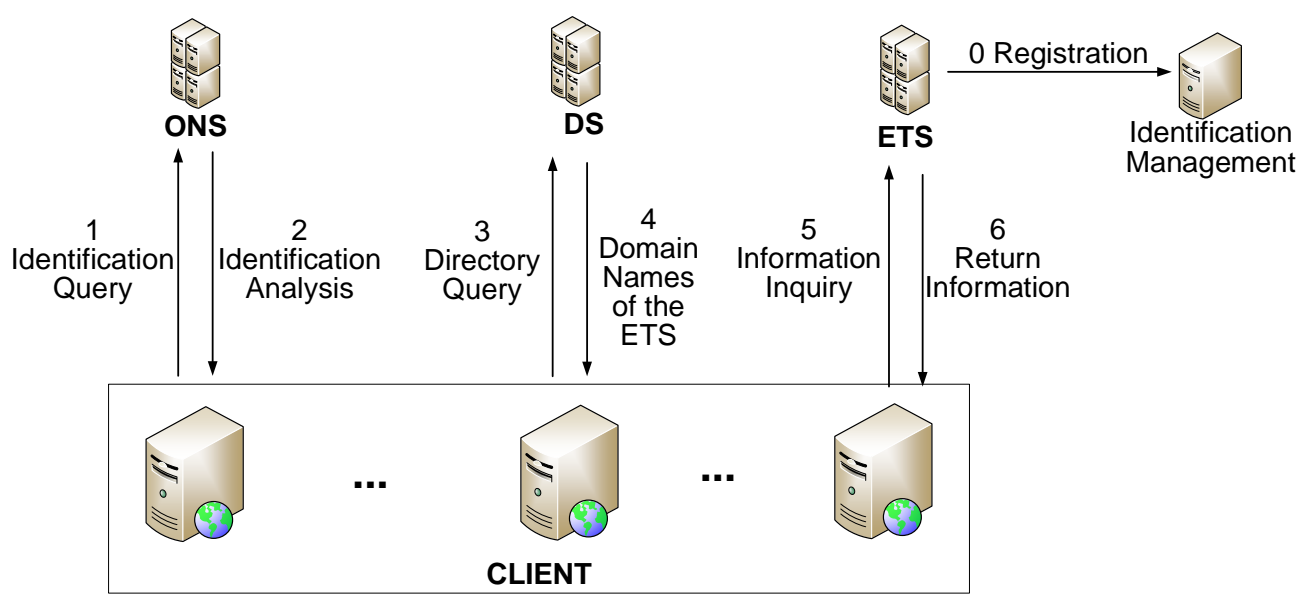

Figure 2. The operation process of the traceability service platform.

As shown in Figure 2, first, the reader reads the EPC code on the RFID of all equipment, devices, and systems in the life cycle of a wind turbine. The collected data are transmitted to the ONS through the middleware of the EPC. Next, based on the mapping of the code identification to the resource entrance, the ONS analyses the identification and sends the results to users. Then, users query the directory through the DS. The domain names of the ETS can be accessed since the DS is mainly deployed to offer index access to the ETS. Each enterprise automatically submits event indexes to the corresponding DS server. Finally, the product information and traceability information are obtained by querying the entry address of the ETS.

\subsubsection{Traceability Management Platform}

The TMP collects and processes the massive amounts of data that are provided by the TSP. It consists of the data service system, monitoring and warning system, and model management system. The data service system includes various regulatory applications (application components and API standards) and achieves the function of collaborative data sharing with relevant institutions, such as testing and certification institutions. The monitoring and warning system performs fault prediction, monitoring and early warning, power generation performance prediction, and emergency command by comparing actual data and indicators. The model management system consists of the power generation prediction models, fault prediction models, and early risk warning models.

\subsection{Application Layer}

\subsubsection{Application Services for Regulatory Authorities}

The application services for regulatory authorities mainly include information query, emergency response, and policymaking:

- Information query: The flow and distribution information of wind turbines and their key components are obtained through related data traceability.

- Emergency response: The supervision and disposal are performed in advance by setting early warning thresholds, and related manufacturers are informed about recalling the flawed products if that is necessary. The recall records include the name, trademark, production date and batch, recall quantity, recall area, recall reason, recall 
effect, the person in charge of the recall, and all other product-related information of interest.

- Policymaking: Based on the risk assessment and early warning information, the relevant policies of wind power generation are developed.

\subsubsection{Application Services for Third-Party Organizations}

The application services for third-party organizations include providing statistical analysis of traceability data, enterprise credit evaluation, and product quality evaluation. Meanwhile, the further application value of traceability data in third-party organizations can be fully explored.

\subsubsection{Application Services for Enterprises}

The enterprise-oriented application services are shown in Table 3.

Table 3. The enterprise-oriented application services.

\begin{tabular}{|c|c|c|c|c|c|c|}
\hline Design & $\begin{array}{l}\text { Raw Material } \\
\text { Acquisition }\end{array}$ & $\begin{array}{l}\text { Production and } \\
\text { Manufacturing }\end{array}$ & $\begin{array}{l}\text { Testing and } \\
\text { Certification }\end{array}$ & $\begin{array}{c}\text { Transaction } \\
\text { and } \\
\text { Transportation }\end{array}$ & Installation & $\begin{array}{l}\text { Operation and } \\
\text { Maintenance }\end{array}$ \\
\hline $\begin{array}{l}\text { Design } \\
\text { report man- } \\
\text { agement }\end{array}$ & $\begin{array}{c}\text { Supplier } \\
\text { management, } \\
\text { raw material } \\
\text { management }\end{array}$ & $\begin{array}{c}\text { Manufacturing } \\
\text { management, } \\
\text { after-sales } \\
\text { management, } \\
\text { assembly } \\
\text { supervision, } \\
\text { statistical analysis } \\
\text { of traceability data, } \\
\text { quality system } \\
\text { construction, } \\
\text { integrating with } \\
\text { enterprise } \\
\text { information } \\
\text { systems }\end{array}$ & $\begin{array}{l}\text { Testing and } \\
\text { certification } \\
\text { report } \\
\text { management }\end{array}$ & $\begin{array}{l}\text { Transaction } \\
\text { supervision, } \\
\text { transport } \\
\text { supervision }\end{array}$ & $\begin{array}{l}\text { Installation } \\
\text { supervision }\end{array}$ & $\begin{array}{l}\text { Spare parts } \\
\text { management, } \\
\text { tracing and inquiry, } \\
\text { operation and } \\
\text { maintenance } \\
\text { supervision, fault } \\
\text { statistical analysis, } \\
\text { fault warning, } \\
\text { information report, } \\
\text { integrating with } \\
\text { the Supervisory } \\
\text { Control and Data } \\
\text { Acquisition } \\
\text { (SCADA) system }\end{array}$ \\
\hline
\end{tabular}

Among the application services given in Table 2, the main applications are as follows:

- Manufacturing management: The manufacturing efficiency can be improved by integrating all the data about the system (e.g., material data, manufacturing data, quality control data, and warehouse management data). The workshop progress and product quality are supervised in real time by the traceability data.

- After-sales management: Manufacturers can repair or recall products with quality problems in time. Furthermore, wind farms are reminded to pay attention to safety issues.

- Information report: The system supports failure reporting and the disclosure of defective products for wind farms.

- $\quad$ Spare parts management: When a wind turbine breaks down and damaged parts need replacement, a wind farm can query the model, inventory quantity, purchase statistics, and consumption statistics of spare parts in time, which significantly improves the response speed and maintenance efficiency.

- Information query: Wind farms can obtain all relevant information on a wind turbine in the supply chain and its responsible enterprise at each stage.

\section{Prototype System Implementation}

Based on the proposed architecture, a traceability prototype system for wind turbines was developed. It was designed using B/S architecture, which is convenient to operate and easy to maintain. 
During the process of traceability, it is necessary to identify the key components of wind turbines first, and then find out the specific information of the component stored in the database or server. The details of the traceability process are as follows.

\subsection{Design Stage}

This stage mainly includes the information management of the design subject and design scheme. There are different concerns for different key components. For instance, for blades, the focus is on the aerodynamic design, structural design, and lightning protection system design, while for the gearbox, the focus is on the gear reliability design, gear precision, bearing reliability, and lubrication.

\subsection{Raw Material Acquisition Stage}

Raw materials include parts, components, and semi-manufactures. An unreasonable purchase can cause poor performance of wind turbines, especially for key components. Therefore, all the suppliers of key components are considered in this stage.

\subsection{Production and Manufacturing Stage}

The raw materials, manufacturing process, technical personnel, and equipment are supervised, and the process is as follows.

\subsubsection{Coding}

The unique identification of products denotes the basis of the ETS. The SGTIN-96 of the EPC coding system was adopted, and RFID tags were chosen as identification carriers. The key components need to be coded before entering the warehouse. Each actor in the supply chain is uniquely identified by a numeric code, namely, a Global Location Number (GLN).

\subsubsection{Storing the Raw Materials}

Each batch of products is sampled, and the relevant information and warehouse location are uploaded to the ETS. Fast conversion of the batch information is realized via code scanning.

\subsubsection{Taking out the Raw Materials}

The raw materials should be taken out of the warehouse according to the production planning instruction, and the information on the batch and quantity of products are collected and stored in the system. The material information is collected via code scanning to realize the association of material batch information. Meanwhile, the error-proofing management of materials is achieved based on the bill of materials.

\subsubsection{Production and Manufacturing}

The products should be manufactured according to the master production plan. The information on the project, batch of materials, quantity, process quality control, and other information on each process is forwarded to the ETS by the EIS. In order to realize personnel traceability, it is necessary to establish the unique identification of personnel by means of two-dimensional codes. By scanning the codes, the information record of personnel work is completed.

\subsubsection{Labelling the Finished Products}

After the completion of products, the labeling is carried out, and the system associates the information on personnel, materials, and equipment with the corresponding RFID tags.

\subsection{Inspection and Testing Stage}

Each wind turbine should be inspected and tested before delivery according to the relevant standards. All the reports should be uploaded to the system. In addition, type 
inspection must be performed when resuming production after a long-term shutdown or greatly changing the production structure, materials, and process.

\subsection{Transaction and Transportation Stage}

The upstream and downstream transaction information and transportation process information are collected and managed. The information on the flow direction, batch, and quantity of products is obtained via outbound scanning and after-sales service tracing.

\subsection{Installation Stage}

This stage mainly includes the information management of the assembly subject, assembly equipment, and assembly acceptance, and involves the processes of foundation construction, tower hoisting, blade assembly, and engine room installation.

\subsection{Operation and Maintenance Stage}

This stage mainly collects and manages the maintenance information and spare parts information of the wind turbine and acquires the operation data and fault data using the supervisory control and data acquisition system (SCADA) to comprehensively assess the quality of the wind turbines.

\section{Discussion}

In this paper, the characteristics of the proposed system are discussed in terms of three aspects: traceability efficiency, information security, and scalability.

\subsection{Traceability Efficiency}

The traceability efficiency is crucial for a traceability system, which can effectively reflect whether the system can provide timely feedback information according to user needs. For the servers with the same configuration, the lower the data pressure, the higher the traceability efficiency. Therefore, the traceability efficiency of different systems can be discussed by analyzing the information amount in a single server.

Suppose the numbers of manufacturing enterprises and wind farms are $X$ and $Y$, respectively. Therefore, the DS servers number of the proposed system is $X+Y$, and the number of enterprises participating in the traceability system is $4 X+3 Y$. Each ETS has its ONS server. We also suppose that the number of key components produced by each manufacturer is N. Each component goes through seven stages in its life cycle. Furthermore, the information numbers of enterprises, products, location, environment, and events are 7 , $8,7,7$, and 20, respectively; the details are given in Table 2 . Therefore, the total information amount is $(4 X+3 Y) \times N \times 49$.

The comparison between the centralized traceability system and the proposed system is shown in Table 4. The results show that the information amount per DS server of the proposed system is relatively small, which results in lower data pressure and higher traceability efficiency. Moreover, with an increasing number of requests, the query speed of the centralized system becomes slower, while the proposed system has few changes.

Table 4. The average information amount of different traceability systems.

\begin{tabular}{ccc}
\hline Traceability System & Numbers of DS Servers & $\begin{array}{c}\text { Information Amount Per DS } \\
\text { Server }\end{array}$ \\
\hline $\begin{array}{c}\text { Centralized traceability system } \\
\text { Semi-centralized traceability } \\
\text { system (the proposed system) }\end{array}$ & 1 & $(4 X+3 Y) \times N \times 49$ \\
& $X+Y$ & $\frac{(4 X+3 Y) \times N \times 49}{X+Y}$ \\
\hline
\end{tabular}

\subsection{Information Security}

It is particularly important to ensure the authenticity and reliability of the information in the process of traceability. Information insecurity events, such as data leakage, data loss, 
or data tampering are mainly caused by the system being attacked. Therefore, information security can be discussed by analyzing the probability of the whole system being attacked.

We assume that all the servers in the system are in the same circumstances and the probability of each DS server being attacked is $\mathrm{p} \%$; thus, the information security probability of each DS server is $1-\mathrm{p} \%$. For the distributed traceability system, all the data are scattered in each enterprise and the DS number is the same as the participating enterprises' number, which is $4 X+3 Y$. The comparison between the distributed traceability system and the proposed system is shown in Table 5. Moreover, the results show that the probability of the proposed system being attacked is lower, which means that the information about manufacturing enterprises and wind farms is more secure.

Table 5. Information security of different traceability systems.

\begin{tabular}{cccc}
\hline Traceability System & $\begin{array}{c}\text { Numbers of DS } \\
\text { Servers }\end{array}$ & $\begin{array}{c}\text { Probability of } \\
\text { System Security }\end{array}$ & $\begin{array}{c}\text { Probability of } \\
\text { System Being } \\
\text { Attacked }\end{array}$ \\
\hline $\begin{array}{c}\text { Semi-centralized } \\
\text { traceability system } \\
\text { (the proposed system) } \\
\begin{array}{c}\text { Distributed } \\
\text { traceability system }\end{array}\end{array}$ & $X+Y$ & $(1-\mathrm{p} \%)^{X+Y}$ & $1-(1-\mathrm{p} \%)^{X+Y}$ \\
\hline
\end{tabular}

\subsection{Scalability}

When the user number reaches the peak and continues to increase, the system performance can not meet the needs of traceability. For this reason, good scalability is very important for the traceability system. The overall scalability of the system in various circumstances can be determined by concurrent testing. As one of the core indexes to evaluate whether the traceability system can bear a large amount of data, concurrent load testing is a process of gradually increasing the load and pressure on the servers until the maximum.

In this study, in order to evaluate the overall scalability of the proposed architecture, concurrent load testing was performed under different conditions by increasing the number of concurrent users. For one ETS, the test results are shown in Table 6.

Table 6. The load test results under different conditions.

\begin{tabular}{|c|c|c|c|}
\hline Test Condition & $\begin{array}{c}\text { Acceptable Concurrency } \\
\text { Number (Return Result in } 1 \mathrm{~s} \text { ) }\end{array}$ & $\begin{array}{c}\text { Acceptable Concurrency } \\
\text { Number (Return Result in } 3 \text { s) }\end{array}$ & $\begin{array}{c}\text { Acceptable Concurrency } \\
\text { Number (Return Result in } 5 \text { s) }\end{array}$ \\
\hline $\begin{array}{l}\text { ONS, DS, and ETS are } \\
\text { deployed on the } \\
\text { same server }\end{array}$ & 910 & 3305 & 4785 \\
\hline $\begin{array}{l}\text { ONS and DS are deployed } \\
\text { on the same server, while } \\
\text { ETS is deployed on } \\
\text { another server }\end{array}$ & 1850 & 5625 & 9430 \\
\hline $\begin{array}{c}\text { ONS, DS, and ETS are } \\
\text { deployed on } \\
\text { different servers }\end{array}$ & 2750 & 8750 & 14,050 \\
\hline
\end{tabular}

The test results show that adding servers to the architecture can greatly improve the overall performance of the traceability, which indicates that the proposed architecture performs well when scaled up.

In addition, the platform extends the traceability chain by integrating the after-sales information, which is conducive to the effective analysis and utilization of traceability data. 


\section{Conclusions}

The reliable operation and stable control of wind turbines are crucial for the rapid development of the wind power industry. With the development of wind power technology, the structure of wind turbines has become more and more complex, thus causing many random and complex problems. Through the traceability of key components of wind turbines during their life cycle, the on-site problems can be easily solved, and the operation and maintenance cost can be reduced to a great degree.

To address the current lack of a proper traceability system in the wind power industry, various user requirements and information on key components of wind turbines are profoundly studied. On this basis, considering the large scale of both manufacturing enterprises of wind turbines and wind farms, an IoT-based semi-centralized traceability platform is put forward, which consists of the enterprise traceability system, traceability service platform, and traceability management platform, and complies with the GS1 standards. Different from the existing traceability systems, the proposed platform is wind-turbineoriented and pays more attention to the after-sale stages than the stages from production to sales to make full use of the traceability data. Compared with a centralized or distributed traceability system, the proposed platform can fully integrate all aspects of the data, disperse data pressure, improve traceability efficiency, and ensure information security.

Through the tracing of the whole life cycle of wind turbines, human errors in production and manufacturing can be reduced and flawed products can be rapidly identified by supervising the important processes, such as batching, rechecking, placing, and finished product shipping. Moreover, it is helpful to enhance the quality control of enterprises and enhance the government's supervision of wind farms.

In future work, blockchain technology will be used to improve the security of the system, and machine learning technology will be used to evaluate the reliability of the system.

Author Contributions: Conceptualization, J.A.; data curation, J.A.; funding acquisition, L.Z.; investigation, J.A.; methodology, G.C. and Z.Z.; project administration, Y.S.; resources, Y.S.; software, J.A.; supervision, R.L. and L.Z.; validation, G.C. and Z.Z.; visualization, J.A.; writing-original draft, J.A.; writing-review and editing, G.C. and Z.Z. All authors have read and agreed to the published version of the manuscript.

Funding: This research was funded by the Shanghai Important Product Traceability Engineering Technology Research Center.

Institutional Review Board Statement: Not applicable.

Data Availability Statement: The data presented in this study are available on request from the corresponding author. The data are not publicly available due to privacy reasons.

Conflicts of Interest: The authors declare no conflict of interest.

\section{References}

1. Gonzalez, E.; Ortego, A.; Topham, E.; Valero, A. Is the future development of wind energy compromised by the availability of raw materials? J. Phys. Conf. Ser. 2018, 1102, 012028. [CrossRef]

2. Nazir, M.S.; Mahdi, A.J.; Bilal, M.; Sohail, H.M.; Ali, N.; Iqbal, H.M. Environmental impact and pollution-related challenges of renewable wind energy-A review. Sci. Total Environ. 2019, 683, 436-444. [CrossRef]

3. Dayal, K.K.; Cater, J.E.; Kingan, M.J.; Bellon, G.D.; Sharma, R.N. Wind resource assessment and energy potential of selected locations in Fiji. Renew. Energy 2021, 172, 219-237. [CrossRef]

4. Serrano-González, J.; Lacal-Arántegui, R. Technological evolution of onshore wind turbines-A market-based analysis. Wind Energy 2016, 19, 2171-2187. [CrossRef]

5. ISO 9000: 2005 Quality Management Systems-Fundamentals and Vocabulary. Available online: https://www.iso.org/standard/ 42180.html (accessed on 14 December 2020).

6. Atzori, L.; Iera, A. The Internet of Things: A survey. Comput. Netw. 2010, 54, 2787-2805. [CrossRef]

7. Miorandi, D.; Sicari, S.; De Pellegrini, F.; Chlamtac, I. Internet of things: Vision, applications and research challenges. Ad Hoc Netw. 2012, 10, 1497-1516. [CrossRef]

8. Huang, J.; Meng, Y.; Gong, X.; Liu, Y.; Duan, Q. A novel deployment scheme for green internet of things. IEEE. Internet Things J. 2014, 1, 196-205. [CrossRef] 
9. Bandyopadhyay, D.; Sen, J. Internet of things: Applications and challenges in technology and standardization. Wirel. Pers. Commun. 2011, 58, 49-69. [CrossRef]

10. Xu, L.; He, W. Internet of things in industries: A survey. IEEE Trans. Ind. Inform. 2014, 10, 2233-2243. [CrossRef]

11. Borowski, P. Innovative processes in managing an enterprise from the energy and food sector in the era of industry 4.0. Processes 2021, 9, 381. [CrossRef]

12. Motlagh, N.H.; Mohammadrezaei, M.; Hunt, J.; Zakeri, B. Internet of things (IoT) and the energy sector. Energies 2020, $13,494$. [CrossRef]

13. Borowski, P. Digitization, Digital twins, blockchain, and industry 4.0 as elements of management process in enterprises in the energy sector. Energies 2021, 14, 1885. [CrossRef]

14. Warnock, J.; McMillan, D.; Pilgrim, J.; Shenton, S. Failure rates of offshore wind transmission systems. Energies 2019, 12, 2682. [CrossRef]

15. Su, C.; Hu, Z. Reliability assessment for Chinese domestic wind turbines based on data mining techniques. Wind Energy 2018, 21, 198-209. [CrossRef]

16. Pérez, J.M.P.; Márquez, F.P.G.; Tobias, A.; Papaelias, M. Wind turbine reliability analysis. Renew Sustain Energy Rev. 2013, 23, 463-472. [CrossRef]

17. Faulstich, S.; Hahn, B.; Tavner, P.J. Wind turbine downtime and its importance for offshore deployment. Wind Energy 2011, 14, 327-337. [CrossRef]

18. Guo, Y.; Zhao, Z.; Sun, R.; Chen, X. Data-driven multiscale sparse representation for bearing fault diagnosis in wind turbine. Wind Energy 2019, 22, 587-604. [CrossRef]

19. Florescu, A.; Barabas, S.; Dobrescu, T. Research on increasing the performance of wind power plants for sustainable development. Sustainability. 2019, 11, 1266. [CrossRef]

20. Papatzimos, A.K.; Thies, P.R.; Dawood, T. Offshore wind turbine fault alarm prediction. Wind Energy 2019, 22, 1779-1788. [CrossRef]

21. Slimacek, V.; Lindqvist, B.H. Reliability of wind turbines modeled by a poisson process with covariates, unobserved heterogeneity and seasonality. Wind Energy 2016, 19, 1991-2002. [CrossRef]

22. Syahputra, R.; Robandi, I.; Ashari, M. Modeling and Simulation of Wind Energy Conversion System in Distributed Gener-ation Units. In Proceedings of the International Seminar on Applied Technology, Science and Arts (APTECS), Surabaya, Indonesia, 6 December 2011.

23. Shin, J.-H.; Lee, J.-H.; Chang, S.-M. A simplified numerical model for the prediction of wake interaction in multiple wind turbines. Energies 2019, 12, 4122. [CrossRef]

24. Donadio, L.; Fang, J.; Porté-Agel, F. Numerical weather prediction and artificial neural network coupling for wind energy forecast. Energies 2021, 14, 338. [CrossRef]

25. Ahuir-Torres, J.I.; Bausch, N.; Farrar, A.; Webb, S.; Simandjuntak, S.; Nash, A.; Thomas, B.; Muna, J.; Jonsson, C.; Mathew, D. Benchmarking parameters for remote electrochemical corrosion detection and monitoring of offshore wind turbine structures. Wind Energy 2019, 22, 857-876. [CrossRef]

26. Liew, H.F.; Rosemizi, A.R.; Aihsan, M.Z.; Muzamir, I.; Baharuddin, I. Wind characterization by three blade savonius wind turbine using iot. IOP Conf. Ser. Mater. Sci. Eng. 2020, 932, 012080. [CrossRef]

27. Noor, A.R.M.; Khyam, M.O. Sensor fusion and state estimation of iot enabled wind energy conversion system. Sensors 2019, 19, 1566. [CrossRef]

28. Zhou, H.; Yi, S.-J.; Liu, Y.-F.; Hu, Y.-Q.; Xiang, Y. A fatigue life prediction method for the drive system of wind turbine using internet of things. Adv. Mater. Sci. Eng. 2020, 2020, 1-8. [CrossRef]

29. Yeh, C.-H.; Lin, M.-H.; Lin, C.-H.; Yu, C.-E.; Chen, M.-J. Machine learning for long cycle maintenance prediction of wind turbine. Sensors 2019, 19, 1671. [CrossRef]

30. Tao, F.; Wang, Y.; Zuo, Y.; Yang, H.; Zhang, M. Internet of things in product life-cycle energy management. J. Ind. Inf. Integr. 2016, 1, 26-39. [CrossRef]

31. Luo, H.; Li, Y.; Liu, N.; Ouyang, Y.; Yuan, F. Design of a Distributed Food Traceability Platform and Its Application in Food Traceability at Guangdong Province. MATEC Web Conf. 2017, 128, 4014. [CrossRef]

32. Visconti, P.; De Fazio, R. Development of sensors-based agri-food traceability system remotely managed by a software platform for optimized farm management. Sensors 2020, 20, 3632. [CrossRef]

33. Wei, Y. Blockchain-based Data Traceability Platform Architecture for Supply Chain Management. In Proceedings of the 2020 IEEE 6th Intl Conference on Big Data Security on Cloud (BigDataSecurity), IEEE Intl Conference on High Performance and Smart Computing, (HPSC) and IEEE Intl Conference on Intelligent Data and Security (IDS), Baltimore, MD, USA, $25-27$ May 2020.

34. Liu, Y.; Han, W.; Zhang, Y.; Li, L.; Wang, J.; Zheng, L. An internet-of-things solution for food safety and quality control: A pilot project in China. J. Ind. Inf. Integr. 2016, 3, 1-7. [CrossRef]

35. Liu, Y.; Wang, H.; Wang, J.; Qian, K.; Kong, N.; Wang, K.; Shi, Y.; Zheng, L. Enterprise-Oriented IoT Name Service for Agriculture Product Supply Chain Management. 2014 Int. Conf. Identif. Inf. Knowl. Internet Things 2014, 308165, 237-241. [CrossRef]

36. Liu, Y.; Liu, S.; Wang, J.; Qian, K.; Shi, Y.; Zheng, L.; Chen, F.; Kong, N. A Credible food traceability system based on domain name system security extensions. Int. J. Online Eng. 2018, 14, 111-125. [CrossRef] 
37. Appelhanz, S.; Osburg, V.-S.; Toporowski, W.; Schumann, M. Traceability system for capturing, processing and providing consumer-relevant information about wood products: System solution and its economic feasibility. J. Clean. Prod. 2016, 110, 132-148. [CrossRef]

38. Rempel, P.; Mader, P. Preventing defects: The impact of requirements traceability completeness on software quality. IEEE Trans. Softw. Eng. 2017, 43, 777-797. [CrossRef]

39. Wang, W.; Niu, N.; Alenazi, M.; Da Xu, L. In-Place traceability for automated production systems: A survey of PLC and SysML tools. IEEE Trans. Ind. Inform. 2019, 15, 3155-3162. [CrossRef]

40. Vukatana, K.; Sevrani, K.; Hoxha, E. Wine traceability: A data model and prototype in albanian context. Foods 2016, 5, 11. [CrossRef] [PubMed]

41. Fernandez-Carames, T.M.; Fraga-Lamas, P. A review on the use of blockchain for the internet of things. IEEE Access 2018, 6, 32979-33001. [CrossRef]

42. Feng, T. An agri-food supply chain traceability system for China based on RFID \& blockchain technology. In Proceedings of the 13th International Conference on Service Systems and Service Management (ICSSSM), Kunming, China, $24-26$ June 2016.

43. Lin, Q.; Wang, H.; Pei, X.; Wang, J. Food safety traceability system based on blockchain and epcis. IEEE Access 2019, 7, $20698-20707$. [CrossRef]

44. Cao, Y.; Jia, F.; Manogaran, G. Efficient traceability systems of steel products using blockchain-based industrial internet of things. IEEE Trans. Ind. Inform. 2019, 16, 6004-6012. [CrossRef]

45. Tsang, Y.P.; Choy, K.L.; Wu, C.H.; Ho, G.T.S.; Lam, H.Y. Blockchain-Driven IoT for food traceability with an integrated consensus mechanism. IEEE Access 2019, 7, 129000-129017. [CrossRef]

46. Li, M.; Weng, J.; Yang, A.; Lu, W.; Zhang, Y.; Hou, L.; Liu, J.-N.; Xiang, Y.; Deng, R.H. CrowdBC: A blockchain-based decentralized framework for crowdsourcing. IEEE Trans. Parallel Distrib. Syst. 2019, 30, 1251-1266. [CrossRef]

47. Hu, L.; Xiang, C.; Qi, C. Research on traceability of cold chain logistics based on RFID and EPC. IOP Conf. Ser. Mater. Sci. Eng. 2020, 790, 012167-012172. [CrossRef]

48. GS1 General Specification. Available online: https://www.gs1.org/standards/barcodes-epcrfid-id-keys/gs1-generalspecifications (accessed on 14 December 2020).

49. Object Name Service (ONS) Version 2.0.1. Available online: https:/ /www.gs1.org/standards/epcis/epcis-ons/2-0-1 (accessed on 14 December 2020).

50. Kim, S.; Hong, S.-J. EPCglobal network design using agent-based simulation. J. Simul. 2020, 1-17. [CrossRef]

51. Lin, L. An integrated framework for the development of radio frequency identification technology in the logistics and supply chain management. Comput. Ind. Eng. 2009, 57, 832-842. [CrossRef] 